\title{
Child Neurology: Intractable Epilepsy and Transient Deficits in a Patient With a History of Herpes Simplex Virus Encephalitis
}

Giovanna S. Manzano, MD, Husain H. Danish, MD, Catherine J. Chu, MD, and Eyal Y. Kimchi, MD, PhD

Neurology ${ }^{\circledR}$ 2021;96:679-681. doi:10.1212/WNL.0000000000011606

\author{
Correspondence \\ Dr. Manzano \\ gmanzano@partners.org
}

Herpes simplex virus (HSV) is a neurotropic pathogen that can invade, replicate, establish latency, and reactivate within the CNS. ${ }^{1}$ Potential triggers of reactivation include immunosuppression, fever, and direct insult. ${ }^{1-3}$ HSV reactivation may cause recurrence of an infectious process, herpes simplex encephalitis (HSE), or recurrence of a relatively benign condition, Mollaret meningitis. Here we report the case of a patient with intractable epilepsy following a febrile illness at age 2 thought to be secondary to HSV. She ultimately underwent an anterior corpus callosotomy 2 decades later with a postoperative course complicated by HSV reactivation. Whereas the majority of cases of HSV reactivation occur within the first year of illness, it is important to recognize that this virus may remain dormant for years and later reactivate in the setting of physiologic stress.

\section{Clinical Case}

\section{New-Onset Seizures Following a Febrile Illness}

A 2-year-old girl was developmentally normal until the onset of a febrile illness complicated by new-onset seizures. Her first seizure was prolonged and followed by persistent right hemiparesis, lasting 3 months. Diagnostic workup was notable for a brain MRI demonstrating asymmetric, nonenhancing hyperintensities in bilateral temporal lobes and insulae (figure, A and B). CSF analysis revealed pleocytosis (cell count unknown), normal protein, normal glucose, and negative HSV PCR. Antiepileptic drugs (AEDs) were initiated with adequate seizure control until age 4 . At age 4 , she developed transient right facial asymmetry associated with somnolence and headaches. A lumbar puncture revealed CSF lymphocytic pleocytosis (13 white blood cells, 76\% lymph) and negative HSV PCR (protein and glucose unknown). A month later, she again experienced a prolonged seizure. This prompted a repeat lumbar puncture, which revealed worsened pleocytosis (54 white blood cells, $80 \%$ mono) and elevated protein $(384 \mathrm{mg} / \mathrm{dL})$. HSV PCR was not retested. A brain MRI showed additional new foci of T2 hyperintensity involving the corpus callosum, right insula, and right frontal lobe. A left temporal brain biopsy was performed and HSV viral cultures were negative. During subsequent months, she experienced transient steroidresponsive neurologic deficits. Eleven years after brain biopsy procurement, the specimens were reanalyzed. Prominent chronic inflammation in the leptomeninges, cortex, and superficial white matter with focal, non-necrotizing granuloma formation was appreciated. Antibody to HSV1 and 2 revealed scattered neuronal and glial cells with cytoplasmic staining. Sufficient tissue was not available for PCR-based diagnostics for HSV at time of reanalysis.

\section{Worsening Epilepsy}

At age 10, the frequency of clinical and subclinical electrographic seizures increased. This led to years of AED titration, vagus nerve stimulator placement, and a palliative left anterior temporal lobectomy at age 18 , without complete seizure control. Subsequent development of frequent atonic seizures prompted the performance of an anterior corpus callosotomy at age 

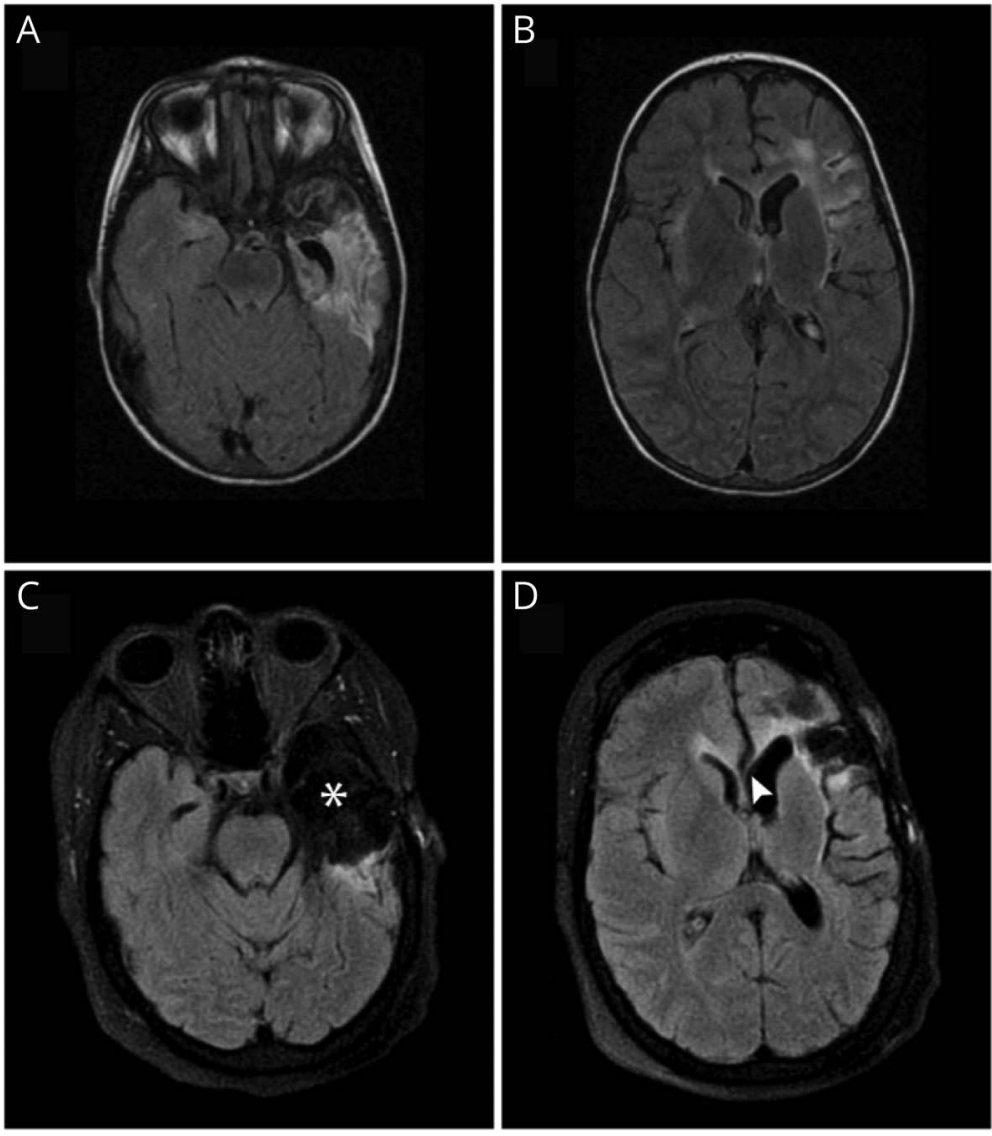

Axial T2 FLAIR brain MRI from presentations at age $3(\mathrm{~A}, \mathrm{~B})$ and age $23(C, D)$ demonstrate diffuse hyperintensities involving the left temporal (A) and frontal (B) regions. Subtle hyperintensities also involve the right temporal and frontal regions (A and B). Corresponding sequences from the patient's presentation at age 23 demonstrate expected postoperative changes following a prior left anterior temporal lobectomy $(C$, *) and recent anterior corpus callosotomy (D, arrowhead).

23. Immediately postoperatively, the patient was at her cognitive and behavioral baseline. Preoperative AEDs (cannabidiol, clobazam, lamotrigine, and levetiracetam) were continued postoperatively.

\section{Postcallosotomy Course}

On postoperative day 2 ( $\mathrm{POD} 2$ ), the patient endorsed a new severe headache, lethargy, and a transient right facial droop. A noncontrast head CT displayed expected postoperative changes. On POD5, she was febrile $\left(37.9^{\circ} \mathrm{C}\right)$, increasingly somnolent, markedly abulic, and exhibited psychomotor slowing. EEG showed no evidence of epileptic seizures. AED levels were therapeutic. A lumbar puncture revealed clear CSF with normal opening pressure (19 cm $\mathrm{H}_{2} \mathrm{O}$ ), lymphocytic pleocytosis (34 and 29 white blood cells, $88 \%$ and $87 \%$ lymph), normal protein (32 mg/ $\mathrm{dL})$, normal glucose $(61 \mathrm{mg} / \mathrm{dL})$, and negative culture and positive HSV-1 DNA by PCR. A brain MRI with and without contrast demonstrated expected postsurgical changes (figure, C and D). A 3-week course of acyclovir monotherapy was administered. A slow steroid taper was concurrently completed. Her alertness and behavior gradually returned to preoperative baseline. She continues to remain free of atonic seizures postprocedurally.

\section{Discussion}

HSV is the most common cause of viral encephalitis in developed countries. ${ }^{2}$ The annual incidence of HSV-1 encephalitis in the United States is estimated to be 4,000 cases, with one-third of these cases affecting children. ${ }^{2}$ As per Infectious Diseases Society of America guidelines, adequate treatment of HSE requires a 3 -week course of acyclovir. ${ }^{2}$ Although recurrence after completed therapy is thought to be uncommon, it has been reported in the literature. HSE recurrence occurs in approximately $5 \%$ of pediatric cases, commonly within weeks to months following initial infection. ${ }^{2}$ In contrast, patients with HSV-related chronic granulomatous inflammation may have intractable epilepsy and viral reactivation years from initial disease. ${ }^{4-6}$ Of note, the published cases of this unusual form of slow smoldering herpes encephalitis were first described after our patient's biopsy was performed. Detection of CSF HSV DNA by PCR is the gold standard for diagnosis of both initial and recurrent infection. This test may be falsely negative when tested too early in the disease course, ${ }^{2}$ if a sample has insufficient cells, or if a less-sensitive, qualitative assay is used. Our patient's intractable epilepsy is likely the sequelae of a remote episode of HSE complicated by chronic granulomatous inflammation. This is supported by her clinical 
course, histopathologic evidence, and positive HSV PCR during her most recent clinical event.

Several genetic mutations are associated with increased susceptibility to HSE and its recurrence. Most mutations involve the interferon $-\alpha / \beta$ and $\gamma$ signaling pathways, as well as the tolllike receptor (TLR) pathway, specifically TLR3., ${ }^{2,5}$ These mutations are thought to disrupt cell-autonomous immunity in neurons and oligodendrocytes. Whole exome sequencing was performed for our patient. Interestingly, it did not detect any mutations or deficiencies known to confer an increased risk of HSE recurrence.

In addition to a recurrent infectious process, HSV reactivation may also cause a recurrent aseptic meningitis, termed Mollaret meningitis. In Mollaret meningitis, recurrent meningeal symptoms last for 2 to 5 days, then spontaneously resolve. ${ }^{7}$ This condition may also variably manifest with seizures, hallucinations, and altered mentation. ${ }^{7}$ Patients typically experience 3 to 10 lifetime events. ${ }^{7}$ CSF analysis reveals lymphocytic pleocytosis and HSV DNA by PCR is almost always positive, more commonly HSV-2. Although Mollaret meningitis is by definition a benign, self-resolving condition, IV acyclovir is administered for suspected cases.?

More recently, postinfectious inflammatory syndromes secondary to HSV have been recognized. Among these is a postHSV autoimmune encephalitis mediated by NMDAR autoantibody. ${ }^{8-10}$ Anti-NMDA encephalitis is critical to identify because early immunotherapy can improve neurologic outcomes. Anti-NMDAR antibody was not tested during our patient's remote episodes. We have since tested our patient for NMDAR autoantibody and it is negative.

Although HSV is widely recognized as a devastating cause of acute encephalitis, it is important to acknowledge its potential long-term sequelae. We recommend that providers have a low threshold to obtain CSF for immunologic and viral testing when patients with a history of HSV develop recurrent neurologic symptoms. Symptom recurrence in this population may be due to either immune-mediated or virally mediated processes, each requiring targeted therapy. In our patient's case, identification of HSV-1 by PCR prompted a complete course of antiviral therapy with acyclovir, ultimately leading to clinical recovery.

\section{Study Funding}

No targeted funding reported.

\section{Disclosure}

The authors report no disclosures relevant to the manuscript. Go to Neurology.org/N for full disclosures.

Appendix Authors

\begin{tabular}{lll}
\hline Name & Location & Contributions \\
\hline $\begin{array}{l}\text { Giovanna S. } \\
\text { Manzano, }\end{array}$ & $\begin{array}{l}\text { Massachusetts } \\
\text { General } \\
\text { Hospital }\end{array}$ & $\begin{array}{l}\text { Drafting/revision of the manuscript } \\
\text { for content, including medical writing } \\
\text { for content; major role in the } \\
\text { acquisition of data; study concept or } \\
\text { design; analysis or interpretation of } \\
\text { data }\end{array}$ \\
\hline $\begin{array}{lll}\text { Husain H. } \\
\text { Danish, MD }\end{array}$ & $\begin{array}{l}\text { Massachusetts } \\
\text { General }\end{array}$ & $\begin{array}{l}\text { Drafting/revision of the manuscript } \\
\text { for content, including medical writing } \\
\text { for content }\end{array}$ \\
\hline $\begin{array}{l}\text { Catherine J. } \\
\text { Chu, MD }\end{array}$ & $\begin{array}{l}\text { Massachusetts } \\
\text { General }\end{array}$ & $\begin{array}{l}\text { Drafting/revision of the manuscript } \\
\text { for content, including medical writing } \\
\text { for content; major role in the } \\
\text { acquisition of data }\end{array}$ \\
\hline $\begin{array}{l}\text { Kospital } \\
\text { Kimchi, }\end{array}$ & $\begin{array}{l}\text { Massachusetts } \\
\text { MD, PhD }\end{array}$ & $\begin{array}{l}\text { Drafting/revision of the manuscript } \\
\text { for content, including medical writing } \\
\text { for content; major role in the }\end{array}$ \\
\hline
\end{tabular}

\section{References}

1. Kleinschmidt-DeMasters BK, Gilden DH. The expanding spectrum of herpesvirus infections of the nervous system. Brain Pathol 2001;11:440-451.

2. Alsweed A, Alsuhibani M, Casanova J-L, et al. Approach to recurrent herpes simplex encephalitis in children. Int J Pediatr Adolesc Med 2018;5:35-38.

3. Mantero V, Cossu M, Rigamonti A, et al. HSV-1 encephalitis relapse after epilepsy surgery: a case report and review of the literature. J Neurovirol 2020;26: $138-141$.

4. Love $\mathrm{S}$, Koch $\mathrm{P}$, Urbach $\mathrm{H}$, et al. Chronic granulomatous herpes simplex encephalitis in children. J Neuropathol Exp Neurol 2004;63:1173-1181.

5. Jay V, Becker L, Blaser S. Pathology of chronic herpes infection associated with seizure disorder: a report of two cases with tissue detection of herpes simplex virus 1 by polymerase chain reaction. Pediatr Pathol Lab Med 1995;15:131-146.

6. Asenbauer B, McEntagart M, King MD, et al. Chronic active destructive herpes simplex encephalitis with recovery of viral DNA 12 years after disease onset. Neuropediatrics 1998;29:120-123.

7. Lim HK, Seppänen M, Hautala T, et al. TLR3 deficiency in herpes simplex encephalitis. Neurology 2014;83:1888-1897.

8. Shalabi M, Whitley RJ. Recurrent benign lymphocytic meningitis. Clin Infect Dis 2006;43:1194-1197.

9. Armangue T, Moris G, Cantarín-Extremera V, et al. Autoimmune post-herpes simplex encephalitis of adults and teenagers. Neurology 2015;85:1736-1743.

10. Prüss H, Finke C, Höltje M, et al. N-Methyl-d-aspartate receptor antibodies in herpes simplex encephalitis. Ann Neurol 2012;72:902-911. 


\section{Neurology}

\section{Child Neurology: Intractable Epilepsy and Transient Deficits in a Patient With a History of Herpes Simplex Virus Encephalitis}

Giovanna S. Manzano, Husain H. Danish, Catherine J. Chu, et al. Neurology 2021;96;679-681 Published Online before print January 25, 2021

DOI 10.1212/WNL.0000000000011606

This information is current as of January 25, 2021

\section{Updated Information \&} Services

References

Subspecialty Collections

Permissions \& Licensing

Reprints including high resolution figures, can be found at: http://n.neurology.org/content/96/14/679.full

This article cites 10 articles, 0 of which you can access for free at: http://n.neurology.org/content/96/14/679.full\#ref-list-1

This article, along with others on similar topics, appears in the following collection(s):

All Epilepsy/Seizures

http://n.neurology.org/cgi/collection/all_epilepsy_seizures All Immunology

http://n.neurology.org/cgi/collection/all_immunology

Autoimmune diseases

http://n.neurology.org/cgi/collection/autoimmune_diseases

Post-infectious

http://n.neurology.org/cgi/collection/postinfectious_

Viral infections

http://n.neurology.org/cgi/collection/viral_infections

Information about reproducing this article in parts (figures,tables) or in its entirety can be found online at:

http://www.neurology.org/about/about_the_journal\#permissions

Information about ordering reprints can be found online:

http://n.neurology.org/subscribers/advertise

Neurology ${ }^{\circledR}$ is the official journal of the American Academy of Neurology. Published continuously since 1951, it is now a weekly with 48 issues per year. Copyright @ 2021 American Academy of Neurology. All rights reserved. Print ISSN: 0028-3878. Online ISSN: 1526-632X.

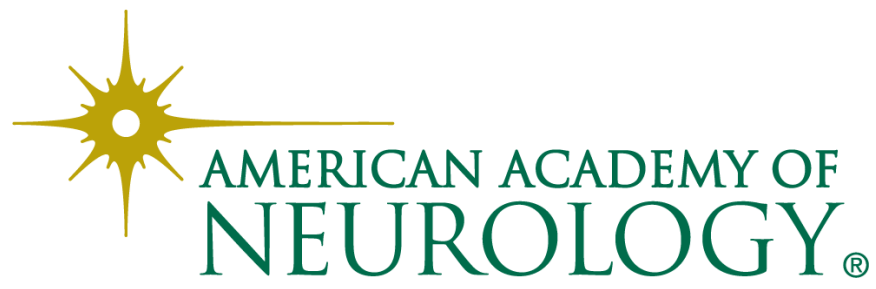

